\title{
Fishing up the Food Web?: 12,000 Years of Maritime Subsistence and Adaptive Adjustments on California's Channel Islands ${ }^{1}$
}

\author{
Fon M. Erlandson, ${ }^{2,5}$ Torben C. Rick, ${ }^{3}$ and Todd F. Braje 4
}

\begin{abstract}
Archaeologists working on California's northern Channel Islands have produced an essentially continuous record of Native American fishing and nearshore ecological changes spanning the last 12,000 years. To search for evidence of Pauly's "fishing down the foodweb" pattern typical of recent historical fisheries, we analyzed variation in the dietary importance of major marine faunal classes (shellfish, fish, marine mammals) on the islands through time. Faunal data suggest that the Island Chumash and their predecessors focused primarily on low-trophic-level shellfish during the Early and Middle Holocene, before shifting their economic focus to finfish and pinnipeds during the Late Holocene. Replicated in faunal sequences from the adjacent mainland, this trans-Holocene pattern suggests that Native Americans fished up the food web, a strategy that may have been more sustainable and had fewer ecological repercussions. Emerging technological data suggest, however, that some of the earliest Channel Islanders focused more heavily on higher-trophic-level animals, including marine mammals, seabirds, and waterfowl. These data emphasize the differences between the primarily subsistence-based foraging strategies of ancient Channel Islanders and the globalized market-based fisheries of modern and historic times, with important implications for understanding the longterm evolution and historical ecology of marine ecosystems.
\end{abstract}

UNTIL QUiTE RECENTLY most scholars believed that humans developed boats, maritime technologies, and intensive fishing economies during only the last 10,000 years or less (see

\footnotetext{
${ }^{1}$ Research has been supported by grants and other assistance from the National Science Foundation, National Park Service, University of Oregon, Southern Methodist University, National Marine Fisheries Service, U.S. Navy, Western Parks Association, the Foundation for Exploration and Research on Cultural Origins, and the Marine Biology Conservation Institute. Manuscript accepted 30 January 2009.

${ }^{2}$ Museum of Natural and Cultural History and Department of Anthropology, University of Oregon, Eugene, Oregon 97403-1224.

${ }^{3}$ Archaeobiology Program, Department of Anthropology, National Museum of Natural History, Smithsonian Institution, Washington D.C. 20013-7012.

${ }^{4}$ Department of Anthropology, Humboldt State University, Arcata, California 95521.

${ }^{5}$ Corresponding author (e-mail: jerland@uoregon. edu).
}

Pacific Science (2009), vol. 63, no. 4:711-724

(C) 2009 by University of Hawai'i Press

All rights reserved
Bailey 2004, Erlandson 2001). Consequently, there was little reason to think that humans colonized most islands or had serious impacts on coastal fisheries and ecosystems until quite late in the Holocene (Erlandson and Rick 2008). This idea may be true for the more remote Pacific islands of Micronesia, Melanesia, and Polynesia, first settled by maritime agriculturalists during the Late Holocene, but it may not apply for many of the lessremote islands of the Pacific Rim, especially Island Southeast Asia, Australia and New Guinea, western Melanesia, and the Ryukyu Islands, which were all colonized by seafaring peoples between $\sim 50,000$ and 35,000 years ago (Erlandson 2002).

The idea that maritime peoples may have contributed to the initial colonization of the Americas has also gained credibility in recent years, as increasingly early sites have been found along the Pacific Coast of the Americas (e.g., Sandweiss et al. 1998, Johnson et al. 2002, Fedje et al. 2004, Des Lauriers 2006, Dillehay et al. 2008, Erlandson et al. 2008a), despite dramatic changes in coastal landscapes 
as global sea levels rose over $100 \mathrm{~m}$ since the end of the Last Glacial. Currently, the earliest evidence for seafaring in the New World comes from California's northern Channel Islands, first settled by maritime Paleocoastal peoples at least 13,000 years ago.

California's Pacific Coast was once thought to have been colonized by interior peoples driven westward by increasing aridity in the desert interior about 7,000 years ago, followed by a gradual adaptation to life by the sea. The intensive maritime fishing societies of Chumash and Tongva peoples of the southern California Coast, first described by Europeans who explored and settled the area from the sixteenth to nineteenth centuries A.D., were thought to have developed only during the last few thousand years. Today, we know that the Channel Islands were first settled by seafaring Paleo-Indians and that relatively intensive coastal economies have probably existed on the islands ever since (Rick et al. 2005, Erlandson et al. 2008a). On San Miguel and Santa Rosa islands alone, almost 40 sites dated from 13,000 to 8,000 years ago have been identified-including the earliest shell middens in North Americaproviding evidence for shellfish collecting, fishing, and the hunting of marine mammals and birds by paleocoastal peoples.

In the last few years, we have used a growing body of high-resolution archaeological and paleoecological data to examine transHolocene patterns of human adaptations and impacts on California's Channel Island ecosystems (e.g., Erlandson et al. 2004, Braje 2007, Rick et al. 2008a). These impacts include possible trophic cascades triggered in kelp forest ecosystems by intensive human hunting of sea otters beginning as early as 8,000 years ago (Erlandson et al. 2005), a measurable decline in the average size of key shellfish prey species through time (Braje et al. 2007, Erlandson et al. 2008b), and the introduction of dogs and foxes to fragile island biota (Rick et al. 2008b, 2009). In this paper, we use faunal and technological records from Channel Islands archaeological sites to examine patterns of fishing and maritime subsistence through the past 12,000 years. Specifically, we address the question of whether ancient fishing patterns follow historical patterns of commercial fishing by focusing first on larger species and higher trophic levels-the "fishing down the food web" pattern identified by Pauly et al. (1998).

In modeling ancient economies, archaeologists often assume that hunter-gatherers focused first on larger species that provided higher caloric returns. The largest animals in terrestrial ecosystems are often herbivores that exist at lower trophic levels, however, and are more abundant than the carnivores that prey on them. In marine ecosystems, the subsistence choices of coastal huntergatherers are influenced by similar economic and ecological principles, as well as issues of differential accessibility (i.e., intertidal versus pelagic) and the need for specialized maritime technologies (seaworthy boats, harpoons, nets, etc.) to access certain habitats and animals. Lacking some of the sophisticated technologies available to modern and historic commercial fisheries, it is uncertain whether prehistoric peoples generally followed similar patterns of focusing first on larger animals and higher trophic levels. Archaeological data provide the opportunity to explore such issues through the examination of faunal assemblages spanning very long sequences of time.

\section{Background}

On California's northern Channel Islands (Figure 1), thousands of archaeological sites contain the remnants of human occupations spanning at least 13,000 years. These sites include numerous shell middens-refuse deposits containing shells, bones, charcoal, artifacts, and other cultural debris left behind by ancient peoples-that provide detailed information on the nature of local terrestrial and marine ecosystems; human hunting, fishing, and foraging patterns; and the changing nature of human impacts on local environments. When Spanish explorers first sailed into the Santa Barbara Channel area in A.D. 1542, they found large and sedentary populations of Chumash Indians living in numerous coastal towns and villages on the mainland and the islands. The densest populations 


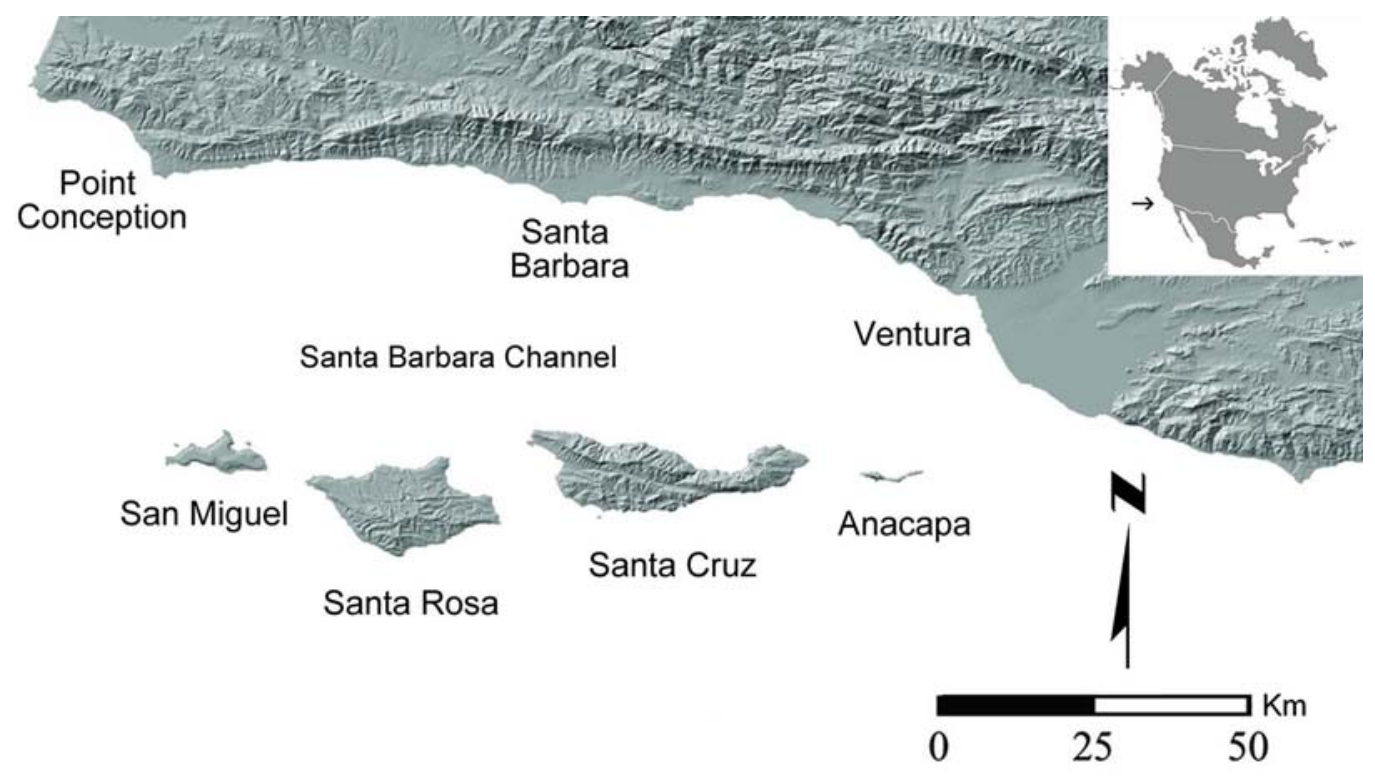

Figure 1. Map of the Santa Barbara Channel and San Miguel Island.

were found around several large and productive estuaries along the mainland coast, where terrestrial plant foods (acorns, etc.) were abundant and a wide variety of animals (deer, fish, shellfish, etc.) were available from marine and terrestrial ecosystems closely stacked between the open ocean and mountains that rise rapidly from the sea. The Island Chumash had far fewer terrestrial resources, in contrast, and relied more heavily on marine resources and trade with mainland peoples (see Arnold 2001, Kennett 2005, Rick 2007). We know that plant foods were an important component of Channel Island economies throughout the Holocene, but preservation problems prevent us from quantitatively assessing their dietary significance.

Along the Santa Barbara mainland coast, faunal assemblages from sites spanning the last 9,000 years show a progressive economic shift from a strong Early and Middle Holocene emphasis on consuming marine and estuarine shellfish-mostly low-trophic-level filter feeders such as mussels and clams (Glassow et al. 1988, Erlandson 1994, 1997) — to Late Holocene fisheries focused on an expanding array of marine finfish and, in some cases, pinnipeds (Glassow and Wilcoxon 1988, Lambert 1993, Erlandson and Rick 2002, Kennett 2005). Dietary reconstructions for faunal remains from mainland sites dating from $\sim 9,000$ to 6,000 years ago suggest that shellfish provided $80 \%-90 \%$ of the edible meat represented, but most sites dating to the past 2,500 years show a reversal, with finfish providing $80 \%-90 \%$ of the edible meat. This shift coincides, in part, with the appearance of $j$-shaped and circular shell fishhooks about 2,500 years ago (Rick et al. 2002), and large pelagic species such as tunas, swordfish, and sharks are more common after about A.D. 500, when the oceangoing Chumash plank canoe seems to have been developed (Gamble 2002, Bernard 2004, Kennett 2005). Other technological data, including numerous milling stones used to process plant foods and projectile points used in hunting, support these dietary and economic reconstructions. Overall, mainland data suggest a long-term pattern of fishing up the food web, the opposite of global patterns in historical and industrial fishing practices.

On the northern Channel Islands, where 
edible plants are more limited in diversity and productivity, early economies may have been quite different than those of the mainland coast. Marine upwelling and extensive kelp forests support an extremely productive marine ecosystem, however, and the modern presence of $>150,000$ pinnipeds (DeLong and Melin 2002) suggests that sea mammals may have been important resources for early maritime peoples. At most Early Holocene sites on the northern Channel Islands for which quantified faunal data are available, shellfish dominate the recovered faunal remains, and dietary reconstructions suggest that shellfish provided most of the edible meat represented (Erlandson et al. 2004, Kennett 2005, Rick et al. 2005, Braje 2007). A diet of shellfish alone can be deficient in carbohydrate and fat content, causing "protein poisoning" (Noli and Avery 1988), but a mixed diet of shellfish, plant foods, and limited amounts of fish, marine mammals, and birds seems to have sustained Channel Islanders for millennia. Fishing was more important at Daisy Cave, where thousands of fish bones were recovered from Paleocoastal strata dated between $\sim 10,000$ and $8,600 \mathrm{cal}$ B.P. (Rick et al. 2001), but dietary reconstructions suggest that sea mammals and birds played a minor economic role.

As on the mainland, both technological and faunal evidence suggest that later Channel Island peoples focused more heavily on marine mammals and especially finfish (Glassow 1993, Lambert 1993, Kennett 2005, Braje et al. 2007). Stable isotope analyses of human skeletons from the region generally support the Late Holocene increase in higher-trophic-level foods enriched in nitrogen (see Walker and DeNiro 1986, Goldberg 1993). Here we use an expanded data set of faunal and artifactual remains from archaeological sites to explore the validity of these patterns and the dynamic nature of maritime subsistence on the northern Channel Islands over the past 12,000 years.

\section{MATERIALS AND METHODS}

Pauly et al. (1998) used twentieth-century fisheries data to identify a general pattern of declining average trophic levels in world fisheries over time. They argued that historical fisheries have tended to focus first on relatively large and long-lived carnivorous species (whales, pinnipeds, swordfish, tunas, cod, etc.), then switch to smaller taxa as fisheries decline or collapse. As a result, commercial fisheries have focused increasingly on higher proportions of smaller fish (herring, sardine, etc.), invertebrates (lobster, shrimp, shellfish, etc.), and other organisms that generally fill the lower trophic levels in ecosystems. This historic pattern of "fishing down the food web" was argued to be unsustainable and deeply problematic because it results in the serial depletion of fisheries and contributes to the collapse of natural ecosystems by triggering trophic cascades and lower biodiversity (see Erlandson and Rick 2008:12-13).

A number of researchers have used this model to search for similar patterns in the deeper historical records offered by long archaeological sequences in coastal areas around the world. The results, which have focused almost exclusively on finfish, have been mixed, with some studies reporting evidence for a reduction in average trophic level exploited through time and others finding little evidence for such a pattern (e.g., Morales and Rosello 2004, Reitz 2004, Bourque et al. 2008). For the northern Channel Islands, finfish are only one of the major marine resources used by the Chumash and their ancestors (Table 1), and understanding the development of fisheries through time requires an integrated view of maritime subsistence that includes shellfish gathering and the hunting of marine mammals and birds.

To examine fishing and marine hunting practices on the northern Channel Islands through time, we used dietary reconstructions from faunal remains recovered from shell midden components spanning the past 12,000 years to estimate the relative contribution of four major classes of marine or aquatic fauna (shellfish, fish, marine mammals, and seabirds/waterfowl). Channel Islands archaeologists have compiled an impressive library of faunal data from transHolocene sequences. The size of the excavated samples and the number of artifacts 


\section{TABLE 1}

Common Shellfish, Finfish, Seabirds, and Pinnipeds in Channel Island Sites

\begin{tabular}{|c|c|c|}
\hline Taxa & Ecology and Behavior & Archaeology \\
\hline \multicolumn{3}{|l|}{ Shellfish } \\
\hline $\begin{array}{l}\text { California mussel } \\
\text { (Mytilus californianus) }\end{array}$ & $\begin{array}{l}\text { Occurs in dense clusters in rocky } \\
\text { intertidal }\end{array}$ & Common in sites throughout Holocene \\
\hline $\begin{array}{l}\text { Black abalone } \\
\text { (Haliotis cracherodii) }\end{array}$ & $\begin{array}{l}\text { Small groups or individuals found in } \\
\text { middle and low intertidal }\end{array}$ & $\begin{array}{l}\text { Low to moderate density in sites } \\
\text { throughout Holocene }\end{array}$ \\
\hline $\begin{array}{l}\text { Red abalone } \\
\text { (Haliotis rufescens) }\end{array}$ & $\begin{array}{l}\text { Small groups or individuals found in } \\
\text { lower middle intertidal to subtidal }\end{array}$ & $\begin{array}{l}\text { Low density in sites throughout } \\
\text { Holocene. Abundant in many sites } \\
\text { dated between } \sim 8,000 \text { to } 3,500 \text { years } \\
\text { ago }\end{array}$ \\
\hline $\begin{array}{l}\text { Owl limpet } \\
\text { (Lottia gigantea) }\end{array}$ & $\begin{array}{l}\text { Territorial individuals found in } \\
\text { middle intertidal }\end{array}$ & $\begin{array}{l}\text { Low to moderate density in sites } \\
\text { throughout Holocene }\end{array}$ \\
\hline $\begin{array}{l}\text { Turban snails } \\
\text { (Tegula spp.) }\end{array}$ & $\begin{array}{l}\text { Moderately dense clusters in upper } \\
\text { intertidal }\end{array}$ & $\begin{array}{l}\text { Low to high density in sites } \\
\text { throughout Holocene }\end{array}$ \\
\hline $\begin{array}{l}\text { Sea urchins } \\
\text { (Strongylocentrotus spp.) }\end{array}$ & Common in intertidal to subtidal & $\begin{array}{l}\text { Low to high density in sites } \\
\text { throughout Holocene }\end{array}$ \\
\hline $\begin{array}{l}\text { Platform mussel } \\
\text { (Septifer bifurcatus) }\end{array}$ & Dense clusters in middle intertidal & $\begin{array}{l}\text { Low to moderate density in sites } \\
\text { throughout Holocene }\end{array}$ \\
\hline \multicolumn{3}{|l|}{ Finfish } \\
\hline $\begin{array}{l}\text { Cabezon } \\
\text { (Scorpaenichthys marmoratus) }\end{array}$ & $\begin{array}{l}\text { Common in rocky intertidal and kelp } \\
\text { forest habitats }\end{array}$ & $\begin{array}{l}\text { Low to moderate density in sites } \\
\text { throughout Holocene }\end{array}$ \\
\hline $\begin{array}{l}\text { California sheephead } \\
\text { (Semicosyphus pulcher) }\end{array}$ & $\begin{array}{l}\text { Common in rocky intertidal and kelp } \\
\text { forest habitats }\end{array}$ & $\begin{array}{l}\text { Low to high density in sites } \\
\text { throughout Holocene }\end{array}$ \\
\hline $\begin{array}{l}\text { Lingcod } \\
\text { (Opbiodon lingatus) }\end{array}$ & $\begin{array}{l}\text { Common in rocky intertidal and kelp } \\
\text { forest habitats }\end{array}$ & $\begin{array}{l}\text { Low density in sites throughout } \\
\text { Holocene }\end{array}$ \\
\hline $\begin{array}{l}\text { Rockfish } \\
\text { (Sebastes spp.) }\end{array}$ & $\begin{array}{l}\text { Common in rocky intertidal and kelp } \\
\text { forest habitats }\end{array}$ & $\begin{array}{l}\text { Low to high density in sites } \\
\text { throughout Holocene }\end{array}$ \\
\hline $\begin{array}{l}\text { Surfperch } \\
\text { (Embiotocidae) }\end{array}$ & $\begin{array}{l}\text { Common in rocky intertidal, sandy } \\
\text { beach, and kelp forest habitats }\end{array}$ & $\begin{array}{l}\text { Low to high density in sites } \\
\text { throughout Holocene }\end{array}$ \\
\hline $\begin{array}{l}\text { Swordfish and marlin } \\
\text { (Xiphiidae) }\end{array}$ & $\begin{array}{l}\text { Found in deepwater and offshore } \\
\text { habitats, occasionally inshore near } \\
\text { submarine canyons }\end{array}$ & $\begin{array}{l}\text { Low density in sites after about A.D. } \\
500\end{array}$ \\
\hline $\begin{array}{l}\text { Tunas } \\
\text { (Scombridae) }\end{array}$ & $\begin{array}{l}\text { Found in deepwater and offshore } \\
\text { habitats, occasionally inshore near } \\
\text { submarine canyons }\end{array}$ & $\begin{array}{l}\text { Low density in sites after about A.D. } \\
500\end{array}$ \\
\hline \multicolumn{3}{|c|}{ 5) } \\
\hline $\begin{array}{l}\text { Auklets } \\
\text { (Alcidae) }\end{array}$ & $\begin{array}{l}\text { Found on rocky shores near coast. } \\
\text { Common on offshore rocks }\end{array}$ & $\begin{array}{l}\text { Generally uncommon, but found in } \\
\text { some Late Holocene sites }\end{array}$ \\
\hline $\begin{array}{l}\text { Brown pelican } \\
\text { (Pelicanus occidentalis) }\end{array}$ & $\begin{array}{l}\text { Found around the coast. Nests in } \\
\text { large colonies }\end{array}$ & $\begin{array}{l}\text { Generally uncommon, but found in } \\
\text { some Late Holocene sites }\end{array}$ \\
\hline $\begin{array}{l}\text { Cormorants } \\
\text { (Phalocrocorax spp.) }\end{array}$ & $\begin{array}{l}\text { Found on rocky shores near coast. } \\
\text { Nests along rocky shores and } \\
\text { ledges }\end{array}$ & $\begin{array}{l}\text { Uncommon, but abundant in some } \\
\text { Middle to Late Holocene sites }\end{array}$ \\
\hline $\begin{array}{l}\text { Gulls } \\
\text { (Laridae) }\end{array}$ & $\begin{array}{l}\text { Found around the coast. Nests in } \\
\text { large colonies }\end{array}$ & $\begin{array}{l}\text { Uncommon, but abundant in some } \\
\text { Middle to Late Holocene sites }\end{array}$ \\
\hline \multicolumn{3}{|l|}{ Pinnipeds and Sea Otters } \\
\hline $\begin{array}{l}\text { Guadalupe fur seal } \\
\text { (Arctocephalus townsendii) }\end{array}$ & $\begin{array}{l}\text { Visit Channel Islands } 12 \text { months per } \\
\text { year. Breeds on rocks at } \\
\text { Guadalupe Island }\end{array}$ & Common in sites after $1,500 \mathrm{cal}$ B.P. \\
\hline $\begin{array}{l}\text { Northern fur seal } \\
\text { (Callorbinus ursinus) }\end{array}$ & $\begin{array}{l}\text { Visit Channel Islands } 4-5 \text { months } \\
\text { per year, skittish. Breeds on sand } \\
\text { and rock beaches }\end{array}$ & Common in sites after $1,500 \mathrm{cal}$ B.P. \\
\hline $\begin{array}{l}\text { Steller sea lion } \\
\text { (Eumetopias jubatus) }\end{array}$ & $\begin{array}{l}\text { Long-range travel at least } 8 \text { months } \\
\text { per year, skittish. Breeds on } \\
\text { beaches and haulouts }\end{array}$ & Rare in sites of any age \\
\hline
\end{tabular}


TABLE 1 (continued)

\begin{tabular}{lcc}
\hline \hline Taxa & Ecology and Behavior & Archaeology \\
\hline $\begin{array}{l}\text { Elephant seal } \\
\text { (Mirounga angustirostris) }\end{array}$ & $\begin{array}{c}\text { Biannual long-range travel at least 8 } \\
\text { months per year, tolerant of } \\
\text { humans. Breeds on beaches and }\end{array}$ & Rare in sites of any age \\
& haulouts & \\
Harbor seal & Year round resident of Channel & Relatively rare in sites of any age \\
(Phoca vitulina) & Islands, skittish. Breeds in water & \\
California sea lion & Females resident; males migrate for & Common in sites after 1,500 cal B.P. \\
(Zalophus californianus) & $<9$ months per year, skittish. & \\
Sea otter & Breeds on beaches & Common in sites after 9,000 cal B.P. \\
(Enhydra lutris) & Year-round residents, skittish, \\
\hline
\end{tabular}

recovered have often been relatively small, however, with a heavy emphasis on small column or bulk samples in which shellfish and fish remains may be relatively well represented but artifacts and sea mammal and bird bones are often underrepresented. Our dietary conversions are based on shell- or bone-to-meat weight conversions (see Glassow and Wilcoxon 1988) that are subject to a variety of sources of error (Erlandson 1994), but such problems tend to be reduced in the stratified and well-preserved shell middens typical of the Channel Islands.

Because average trophic levels are not available for many of the major prey species found in Channel Island archaeological sites (Fishbase contains only finfish, and a broader Sealifebase does not yet contain most of the shellfish, sea mammals, and seabirds represented), we are currently unable to conduct a detailed interspecific and quantitative trophic-level analysis comparable with that of Pauly et al. (1998). The primary shellfish foods (abalone, mussels, turban snails, chitons, limpets, etc.) found in Channel Island middens are primarily herbivores or filter feeders, however, which exist just above primary producers near the base of the food web. Most of the finfish, pinnipeds, and birds exploited, in contrast, are carnivores or omnivores that exist at higher trophic levels. Consequently, our dietary reconstructions can provide general information on the human exploitation of marine trophic levels through time.

\section{RESULTS AND DISCUSSION}

\section{Changing Patterns of Faunal Exploitation}

A substantial body of faunal data from long archaeological sequences on the northern Channel Islands suggests that a general pattern of fishing up the food web may have existed on the islands through most of the Holocene. Glassow (1993) analyzed column samples from 14 Santa Cruz Island middens spanning the past 7,800 calendar years, for instance, documenting a progressive shift from marine shellfish toward finfish through time. In two Early Holocene components dated to about 7,700 and 7,200 years ago, shellfish provide $\sim 90 \%$ of the animal protein represented, with fish and sea mammals each providing about $5 \%$. Several Middle Holocene components, dated from $\sim 6,500$ to 3,500 years ago, show considerable diversity, but sea mammals and finfish provided a growing proportion of the animal protein represented. For 16 components dating to the past 2,500 years, finfish contribute most of the animal protein, followed by sea mammals and shellfish.

Kennett (1998:276) found a similar pattern in analyzing column samples from northern Channel Island sites. Comparing the dietary yields of shellfish versus finfish, he showed that shellfish dominated at most Early and Middle Holocene sites, and finfish dominated in most Late Holocene sites. In four Early Holocene components, shellfish provided an average of $97 \%$ of the edible meat, a figure 
TABLE 2

Estimated Dietary Contributions of Major Marine Faunal Classes in San Miguel Island Shell Middens

\begin{tabular}{|c|c|c|c|c|c|c|}
\hline Site and Component & Age (cal B.P.) & Shellfish & Fish & Sea Mammal & Bird & Reference \\
\hline SMI-678 & $\sim 11,700$ & $100 \%$ & - & - & - & This paper \\
\hline SMI-261: Str. F & $10,000-9,500$ & $77 \%$ & $22 \%$ & $1 \%$ & $<1 \%$ & Erlandson et al. (2004) \\
\hline SMI-608 & $\sim 9,500$ & $95 \%$ & $5 \%$ & $<1 \%$ & - & Braje (2007) \\
\hline SMI-548 & 9,500 & $83 \%$ & $<1 \%$ & $16 \%$ & - & Erlandson et al. (2004) \\
\hline SMI-507 & 9,100 & $99 \%$ & $1 \%$ & - & - & This paper \\
\hline SMI-606 & $9,000-8,600$ & $99 \%$ & $<1 \%$ & $<1 \%$ & $<1 \%$ & This paper \\
\hline SMI-261: Str. E & $9,000-8,600$ & $38 \%$ & $57 \%$ & $5 \%$ & $1 \%$ & Erlandson et al. (2004) \\
\hline SMI-575NE & 8,500 & $100 \%$ & - & - & - & This paper \\
\hline SMI-603: Str. 7 & $8,400-7,500$ & $82 \%$ & $14 \%$ & $1 \%$ & $3 \%$ & Erlandson et al. (2004) \\
\hline SMI-261: Str. C & 6,700 & $68 \%$ & $31 \%$ & - & $1 \%$ & This paper \\
\hline SMI-605 (Otter Cave) & $6,600-6,300$ & $52 \%$ & $33 \%$ & $15 \%$ & - & This paper \\
\hline SMI-657 & 6,000 & $95 \%$ & $4 \%$ & $1 \%$ & - & Braje (2007) \\
\hline SMI-481 & 6,000 & $90 \%$ & $2 \%$ & $8 \%$ & $<1 \%$ & Vellanoweth et al. (2006) \\
\hline SMI-481 & 5,900 & $23 \%$ & $17 \%$ & $60 \%$ & $<1 \%$ & Vellanoweth et al. (2006) \\
\hline SMI-492N & 5,500 & $63 \%$ & $33 \%$ & $4 \%$ & - & Erlandson et al. (2004) \\
\hline SMI-603: Str. 4 & 4,400 & $83 \%$ & $17 \%$ & - & - & Erlandson et al. (2004) \\
\hline SMI-628 & 4,200 & $71 \%$ & $21 \%$ & $7 \%$ & - & Braje (2007) \\
\hline SMI-603: Str. 3 & 4,050 & $58 \%$ & $9 \%$ & $33 \%$ & $1 \%$ & Erlandson et al. (2004) \\
\hline SMI-503: Str. 6 & 3,700 & $56 \%$ & $44 \%$ & - & - & Erlandson et al. (2004) \\
\hline SMI-261: Str. A & 3,400 & $32 \%$ & $41 \%$ & $27 \%$ & - & Vellanoweth et al. (2002) \\
\hline SMI-87 & 2,800 & $40 \%$ & $46 \%$ & $12 \%$ & $2 \%$ & Rick (2007) \\
\hline SMI-525: Str. 27 & 3,000 & $30 \%$ & $70 \%$ & - & - & Erlandson et al. (2004) \\
\hline SMI-603: Str. 2 & 2,400 & $25 \%$ & $52 \%$ & $15 \%$ & $9 \%$ & Erlandson et al. (2004) \\
\hline SMI-628 & 1,400 & $61 \%$ & $30 \%$ & $8 \%$ & - & Braje (2007) \\
\hline SMI-481 & $1,300-1,000$ & $7 \%$ & $21 \%$ & $72 \%$ & - & Erlandson et al. (2004) \\
\hline SMI-528 & 1,250 & $10 \%$ & $16 \%$ & $73 \%$ & - & Erlandson et al. (2004) \\
\hline SMI-232 & 1,200 & $4 \%$ & $26 \%$ & $69 \%$ & - & Braje (2007) \\
\hline SMI-525: Str. 3 & 550 & $15 \%$ & $16 \%$ & $69 \%$ & - & Erlandson et al. (2004) \\
\hline SMI-602 & $500-200$ & $2 \%$ & $74 \%$ & $23 \%$ & $<1 \%$ & Erlandson et al. (2004) \\
\hline SMI-163 & $400-130$ & $22 \%$ & $66 \%$ & $9 \%$ & $3 \%$ & Rick (2007) \\
\hline
\end{tabular}

that dropped to $91 \%$ in 21 Middle Holocene components and $25 \%$ in 39 Late Holocene components. For the 32 Late Holocene components that postdated the introduction of single-piece shell fishhooks $\sim 2,500$ years ago, finfish provided an average of $81 \%$ of the edible meat represented compared with just $19 \%$ for shellfish. In a detailed study of one of Kennett's columns from a 7,300-year sequence at SRI-147 on the south coast of Santa Rosa, Braje et al. (2007) showed a similar shift from shellfish to fish over time, accompanied by a progressive decline in the average size of mussels and other shellfish found in various midden strata.

In our work on San Miguel Island, including a number of sites from which larger excavation samples have been analyzed, we have documented a similar progression through time (Erlandson et al. 2004, Rick et al. 2005, Braje 2007). We now have faunal data and dietary reconstructions from 30 discrete components ranging from about 11,700 to 200 years ago (Table 2 ), including roughly equal numbers of Early, Middle, and Late Holocene sites. For the early sites, finfish provide an average of about $11 \%$ of the edible meat represented, compared with $21 \%$ for Middle Holocene sites, and $42 \%$ for the Late Holocene. In the same components, the importance of shellfish declines from an average of $86 \%$ in the Early Holocene, to $66 \%$ in the Middle Holocene, and to $22 \%$ in the Late Holocene. Sea mammals - consisting primarily of pinnipeds but also including sea otters and some cetaceans-also show substantial changes through time, contributing an average of less than $3 \%$ in Early Holocene sites, 
$14 \%$ in Middle Holocene sites, and 35\% in Late Holocene sites. At least three sites on San Miguel provide faunal evidence for intensive pinniped hunting between about 1,500 and 1,000 years ago (Walker et al. 2002, Braje 2007, Rick 2007). Overall, birds appear to have been a minor food resource throughout the Holocene, although they may have been important at some sites.

Despite the major increases in fish in Late Holocene human diets, people appear to have harvested kelp-forest and rocky-shore species on the Channel Islands that represent a fairly predictable suite of low- to mid-trophic-level fishes (e.g., rockfish [Sebastes spp.], perch [Embiotocidae], and wrasses [Labridae]) throughout much of the last 10,000 years, with the addition of the higher-trophic-level pinnipeds, tunas, and swordfish generally occurring during the last 1,500 years. However, high-trophic-level fishes generally contribute $5 \%$ or less of the total number of individual specimens (NISP) in these Late Holocene finfish assemblages (Pletka 2001, Rick 2007).

\section{Technological Evidence}

At the time of European contact, the coastal and island Chumash had a diverse array of fishing and maritime hunting technologies, including oceangoing boats, fishhooks, harpoons, nets and traps, and other tools used in the gathering, processing, and cooking of marine foods. Archaeological evidence suggests that these complex and sophisticated maritime technologies were developed through time in an additive process. Simple bone bipoints (gorges) were used as fishhooks for nearly 10,000 years, and composite hooks appear to have been introduced during the Middle Holocene (Figure 2), for instance, but the density of fish bone increases substantially in many island sites after the appearance of curved, single-piece fishhooks on the northern Channel Islands about 2,500 years ago (Rick et al. 2002). The development of the relatively large and stable plank canoe, probably about 1,500 years ago (Gamble 2002, Bernard 2004), is associated with more intensive pelagic fishing-including large fish species such as tunas, swordfish, and sharks- and pinniped hunting, as well as more intensive trade between mainland and island peoples, and greater craft specialization, which includes an explosion of shell bead manufacturing on the islands (Kennett 2005, Braje et al. 2007). The appearance of the bow and arrow about the same time may also have increased the efficiency of marine hunting. All these innovations had important economic and demographic repercussions for the Chumash, contributing to population growth during the Late Holocene that spurred organizational changes in Chumash society, including greater cultural complexity, craft specialization, and elite control (see Arnold 2001, Kennett 2005).

For the past 8,000 years or so, technological data seem largely consistent with faunal evidence for broad patterns of subsistence change among the Island Chumash and their ancestors. Recent evidence suggests, however, that faunal records for the terminal Pleistocene and Early Holocene may underestimate the importance of fishing and hunting in early island economies. Bone bipoints (fish gorges) have been found in several sites dating between about 10,000 and 8,000 years ago, for instance, including Daisy Cave where they are associated with over 27,000 fish bones (Rick et al. 2001), demonstrating that Paleocoastal peoples engaged in intensive fishing at some localities. Tantalizing evidence is also emerging for the existence of a sophisticated marine hunting technology among Paleocoastal peoples on the northern Channel Islands. This evidence is found in the form of numerous finely made stemmed and barbed points, chipped stone crescents, and other bifaces found in early island sites (Figure 3). The crescents may have served as transverse projectile points used in bird hunting (Erlandson and Braje 2008) and the delicate Channel Island Barbed points (see Justice 2002) in fishing (Glassow et al. 2008:47) or sea mammal hunting. Their abundance at several San Miguel and Santa Rosa island sites recently dated to the terminal Pleistocene $(\sim 12,200$ to 11,500 cal B.P.) suggests that an important aspect of early island subsistence may be missing from faunal records that suggest a strong focus on shellfish gath- 


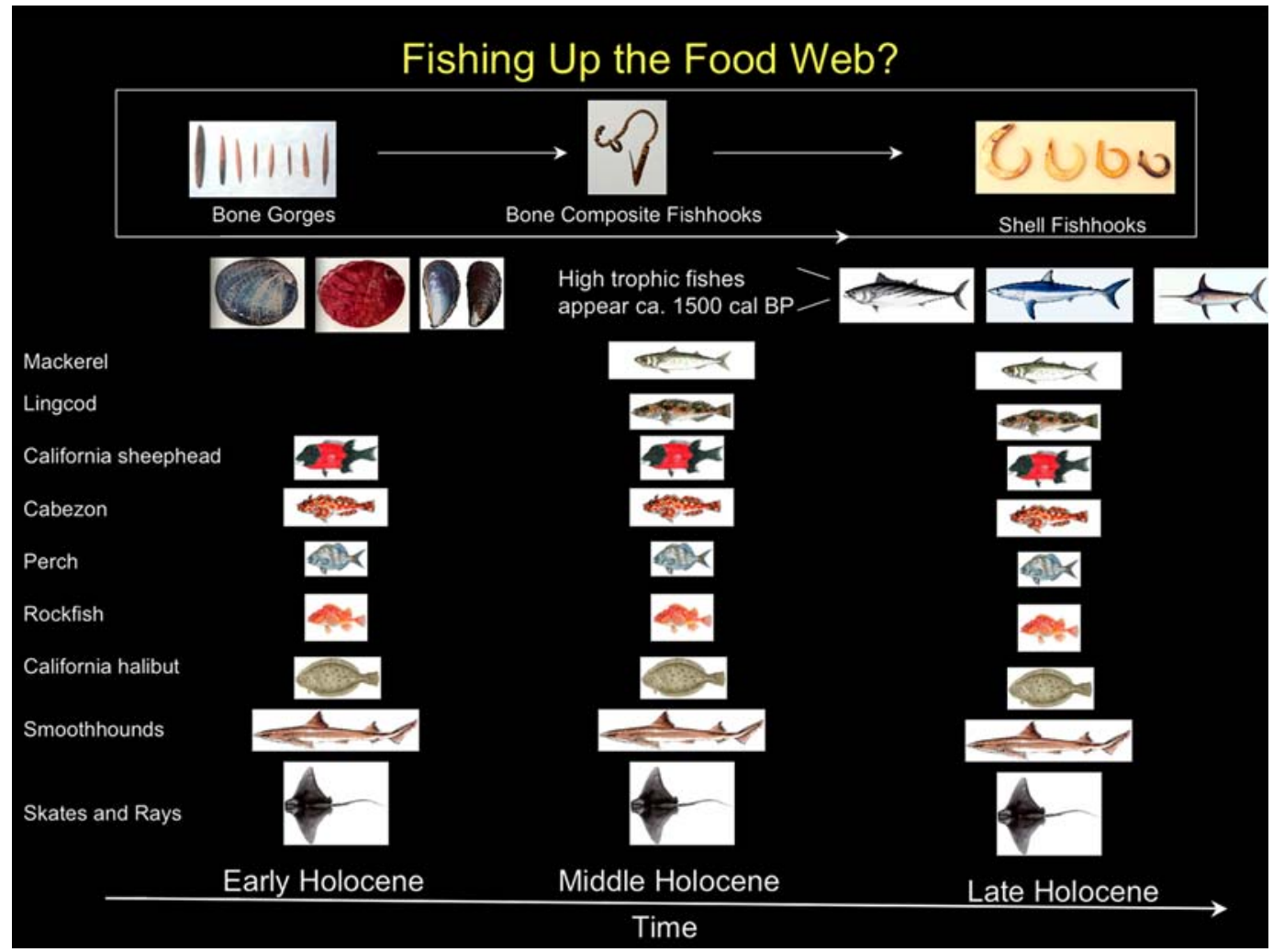

Figure 2. Fishing up the food web: Changes in fish, shellfish, and fishing technologies through the Holocene on the northern Channel Islands (adapted from Rick et al. 2008a). Similar suites of nearshore species dominate most finfish faunal assemblages throughout the Holocene, but tunas, swordfish, and pelagic sharks increase in abundance during the Late Holocene, especially after about 1,500 years ago. Shellfish, especially mussels and abalone, are abundant in island shell middens throughout the past 12,000 years, but their overall economic importance compared with finfish and sea mammals declines through time. Not represented here is emerging technological evidence for more intensive sea mammal and bird hunting before about 8,400 years ago.

ering. Although trans-Holocene faunal records support a general adaptive shift from an early emphasis on low-trophic-level shellfish to a later focus on sea mammals and fish of higher trophic levels, this adaptive pattern may postdate a poorly understood Paleocoastal pattern with a greater emphasis on the hunting of marine mammals and birds than represented in faunal records.

\section{CONCLUSIONS}

By now, marine scientists worldwide have a growing understanding that humans have influenced marine fisheries and ecosystems for centuries or millennia (Pinnegar and Engelhard 2008). The magnitude and geographic extent of these changes have clearly grown since the advent of an increasingly global and industrialized economy (Pauly 1995, Jackson et al. 2001), but earlier people with local and regional economies sometimes strongly influenced the structure and productivity of nearshore marine ecosystems in the deep past (see Rick and Erlandson 2008).

With high population densities; numerous year-round villages; a diversified maritime economy with sophisticated watercraft and other marine hunting and fishing technologies, intensive craft specialization, and 


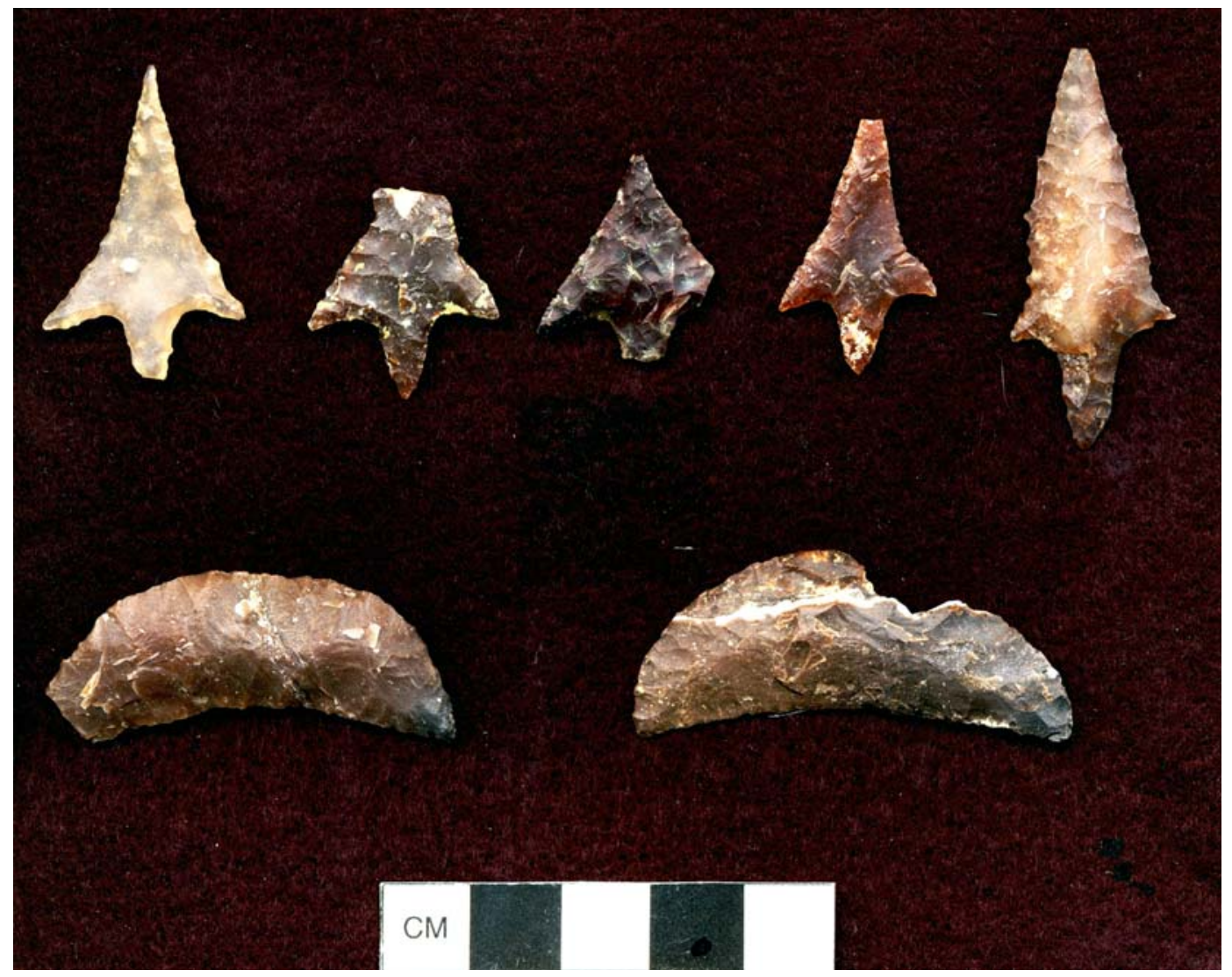

Figure 3. Channel Island Barbed (a.k.a. Arena) points and crescents from a Paleocoastal site on Santa Rosa Island (photo by J.M.E.).

regional trade; and a stratified and entrepreneurial social structure, the Island Chumash were also strong candidates to have had measurable effects on local ecosystems during the last 3,000 years. Archaeological evidence suggests that the anthropogenic impacts of Channel Islanders on intertidal and nearshore ecosystems began much earlier, however, including a trophic cascade caused by a reduction in the number of sea otters living in island waters and later declines in the average size of some key shellfish species (Erlandson et al. 2005, 2008b, Rick et al. 2008a).

Did the Island Chumash and their ancestors follow global historical patterns in "fishing down the food web" (Pauly et al. 1998), or did they practice more sustainable strat- egies that focused first on low-trophic-level shellfish, with pinnipeds and finfish becoming more important through time? Interestingly enough, the answer may be both. A few years ago, the existing faunal evidence argued for a pattern of fishing up the food web that spanned the past 10,000 years (Erlandson et al. 2004). This pattern showed signs of a logical progression of growing human impacts on mussel, abalone, and probably other shellfish populations, followed by the intensification of fishing, seal hunting, and trade with mainland groups (Kennett 2005, Braje et al. 2007). However, recent research on early maritime hunting technologiesespecially the crescents and Channel Island Barbed points found in several Terminal 
Pleistocene and Early Holocene sites-now suggests that the faunal remains from some excavated shell middens may underestimate the importance of marine hunting by Paleocoastal peoples (Erlandson and Braje 2008, Erlandson et al. 2008). These points suggest that the hunting of sea mammals and birds was an important early focus of Paleocoastal economies on the northern Channel Islands, an emphasis on vertebrates that may have been followed by the heavy use of shellfish during the Early and Middle Holocene, then an intensification of marine fishing and sea mammal hunting in the Late Holocene.

These data underscore some of the fundamental differences between the largely subsistence-based economies of ancient Channel Islanders, particularly during the Early and Middle Holocene, and the global, market-based fisheries of the modern and historical periods. Ancient Channel Islanders appear to have made decisions on which marine foods to harvest based on the availability of resources, ease of procurement, size of the population being fed, and the available technologies and marine habitats. Whether ancient Channel Islanders intentionally fished up the food web or this was merely a fortuitous aspect of the structure of their society and nature of local ecosystems, our study illustrates patterns of marine foraging that were relatively sustainable over the long term and fundamentally different from many modern or historical fisheries. Our study also points out the need for researchers interested in reconstructing patterns of ancient trophic-level changes in archaeological sequences to examine relationships between different faunal classes (e.g., fish, birds, marine mammals, and shellfish) to build a broader context for understanding variability in fishing practices, maritime subsistence, and human impacts on marine ecosystems through space and time.

\section{ACKNOWLEDGMENTS}

For facilitating our work in Channel Islands National Park we are grateful to Robert DeLong, Ann Huston, Kelly Minas, Mark Sennig, and Ian Williams. Finally, we thank
Scott Fitzpatrick, Michiko Intoh, and anonymous reviewers for help in the review and publication of this paper.

\section{Literature Cited}

Arnold, J. E. 2001. The origins of a Pacific Coast chiefdom: The Chumash of the Channel Islands. University of Utah Press, Salt Lake City.

Bailey, G. N. 2004. The wider significance of submerged archaeological sites and their relevance to world prehistory. Pages 3-10 in N. C. Flemming, ed. Submarine prehistoric archaeology of the North Sea. Council for British Archaeology Research Report 141.

Bernard, J. L. 2004. Status and the swordfish: The origins of large-species fishing among the Chumash. Pages 25-52 in J. E. Arnold, ed. Foundations of Chumash complexity. Cotsen Institute of Archaeology, University of California, Los Angeles.

Bourque, B. J., B. J. Johnson, and R. S. Steneck. 2008. Possible prehistoric fishing effects on coastal marine food webs in the Gulf of Maine. Pages 165-185 in T. C. Rick and J. M. Erlandson, eds. Human impacts on ancient marine ecosystems: A global perspective. University of California Press, Berkeley.

Braje, T. 2007. Archaeology, human impacts, and historical ecology of San Miguel Island, California. Ph.D. diss., University of Oregon, Eugene.

Braje, T., D. J. Kennett, J. M. Erlandson, and B. Culleton. 2007. Human impacts on nearshore shellfish taxa: A 7,000 year record from Santa Rosa Island, California. Am. Antiq. 72:735-756.

DeLong, R. L., and S. R. Melin. 2002. Thirty years of pinniped research at San Miguel Island. Pages 401-406 in D. R. Browne, K. L. Mitchell, and H. W. Chaney, eds. Proceedings of the 5th California Islands Symposium, Santa Barbara Museum of Natural History, Santa Barbara, California.

Des Lauriers, M. R. 2006. Terminal Pleistocene and Early Holocene occupations of Isla de Cedros, Baja California, Mexico. J. Isl. Coastal Archaeol. 1:255-270. 
Dillehay, T. D., C. Ramírez, M. Pino, M. B. Collins, J. Rossen, and J. D. Pino-Navarro. 2008. Monte Verde: Seaweed, food, medicine, and the peopling of South America. Science (Washington, D.C.) 320:784-786.

Erlandson, J. M. 1994. Early huntergatherers of the California Coast. Plenum, New York.

1997. The Middle Holocene on the California Coast. Perspect. Calif. Archaeol. 4:1-10. Institute of Archaeology, Univ. of Calif., Los Angeles.

. 2001. The archaeology of aquatic adaptations: Paradigms for a new millennium. J. Archaeol. Res. 9:287-350.

2002. Anatomically modern humans, maritime adaptations, and the peopling of the New World. Pages 59-92 in N. Jablonski, ed. The first Americans: The Pleistocene colonization of the New World. Mem. Calif. Acad. Sci., San Francisco.

Erlandson, J. M., and T. J. Braje. 2007. Early maritime technology on California's San Miguel Island: Arena points from CA-SMI575-NE. Curr. Res. Pleistocene 24:85-86. 2008. Five crescents from Cardwell: Context and chronology of chipped stone crescents from CA-SMI-679, San Miguel Island, California. Pac. Coast Archaeol. Soc. Q. 40 (1):35-45.

Erlandson, J. M., M. L. Moss, and M. Des Lauriers. 2008a. Living on the edge: Early maritime cultures of the Pacific Coast of North America. Quat. Sci. Rev. 27:22322245.

Erlandson, J. M., and T. C. Rick. 2002. Late Holocene cultural developments along the Santa Barbara Coast. Pages 166-182 in J. M. Erlandson and T. L. Jones, eds. Catalysts to complexity: The Late Holocene on the California Coast. Cotsen Institute of Archaeology, University of California, Los Angeles.

2008. Archaeology, marine ecology, and human impacts on marine environments. Pages 1-19 in T. C. Rick and J. M. Erlandson, eds. Human impacts on ancient marine ecosystems: A global perspective. University of California Press, Berkeley.

Erlandson, J. M., T. C. Rick, T. J. Braje, A.
Steinberg, and R. L. Vellanoweth. $2008 b$. Human impacts on ancient shellfish: A 10,000 year record from San Miguel Island, California. J. Archaeol. Sci. 35: 2144-2152.

Erlandson, J. M., T. C. Rick, M. Graham, J. Estes, T. Braje, and R. Vellanoweth. 2005. Sea otters, shellfish, and humans: 10,000 years of ecological interaction on San Miguel Island, California. Pages 5869 in D. K. Garcelon and C. A. Schwemm, eds. Proceedings of the 6th California Islands Symposium. Institute for Wildlife Studies and National Park Service, Arcata, California.

Erlandson, J. M., T. C. Rick, and R. L. Vellanoweth. 2004. Human impacts on ancient environments: A case study from California's northern Channel Islands. Pages 51-83 in S. M. Fitzpatrick, ed. Voyages of discovery: The archaeology of islands. Praeger, New York.

Fedje, D. W., Q. Mackie, E. J. Dixon, and T. H. Heaton. 2004. Late Wisconsin environments and archaeological visibility on the northern Northwest Coast. Pages 97138 in D. B. Madsen, ed. Entering America, Northeast Asia and Beringia before the Last Glacial Maximum. University of Utah Press, Salt Lake City.

Gamble, L. H. 2002. Evidence for the origin of the plank canoe in North America. Am. Antiq. 67:301-315.

Glassow, M. A. 1993. Changes in subsistence on marine resources through 7000 years of prehistory on Santa Cruz Island. Pages 75-94 in M. A. Glassow, ed. Archaeology on the northern Channel Islands: Studies of subsistence, economics, and social organization. Coyote Press Archives of California Prehistory 34, Salinas.

Glassow, M. A., P. Paige, and J. Perry. 2008. The Punta Arena site and Early and Middle Holocene cultural development on Santa Cruz Island, California. Anthropol. Pap. Santa Barbara Mus. Nat. Hist., Santa Barbara.

Glassow, M. A., and L. Wilcoxon. 1988. Coastal adaptations near Point Conception, California, with particular regard to shellfish exploitation. Am. Antiq. 53:35-51. 
Glassow, M. A., L. R. Wilcoxon, and J. M. Erlandson. 1988. Cultural and environmental change during the Early period of Santa Barbara Channel prehistory. Pages 64-77 in G. N. Bailey and J. E. Parkington, eds. The archaeology of prehistoric coastlines. Cambridge University Press, Cambridge.

Goldberg, C. F. 1993. The application of stable carbon and nitrogen isotope analysis to human dietary reconstruction in prehistoric southern California. Ph.D. diss., University of California, Los Angeles.

Jackson, J. B. C., M. X. Kirby, W. H. Berger, K. A. Bjorndal, L. W. Botsford, B. J. Bourque, R. H. Bradbury, R. Cooke, J. Erlandson, J. A. Estes, T. P. Hughes, S. Kidwell, C. B. Lange, H. S. Lenihan, J. M. Pandolfi, C. H. Peterson, R. S. Steneck, M. J. Tegner, and R. R. Warner. 2001. Historical overfishing and the recent collapse of coastal ecosystems. Science (Washington, D.C.) 293:629-638.

Johnson, J. R., T. Stafford Jr., H. Ajie, and D. P. Morris. 2002. Arlington Springs revisited. Pages 541-545 in D. Browne, K. Mitchell, and H. Chaney, eds. Proceedings of the 5th California Islands Conference. Santa Barbara Museum of Natural History, Santa Barbara, California.

Justice, N. D. 2002. Stone Age spear and arrow points of California and the Great Basin. Indiana University Press, Bloomington.

Kennett, D. J. 1998. Behavioral ecology and the evolution of hunter-gatherer societies on the northern Channel Islands, California. Ph.D. diss., University of California, Santa Barbara.

- 2005. The Island Chumash: Behavioral ecology of a maritime society. University of California Press, Berkeley.

Lambert, P. M. 1993. Health in prehistoric populations of the Santa Barbara Channel Islands. Am. Antiq. 58:509-522.

Morales, A., and E. Rosello. 2004. Fishing down the food web in Iberian prehistory? A new look at the fishes from Cueva de Nerja (Malaga, Spain). Pages 111-123 in J. Brugal and J. Desse, eds. Pettis animaux et societes humaines du complement ali- mentaire aux resources Utilitaires XXIV. APDCA, Antibes.

Noli, D., and G. Avery. 1988. Protein poisoning and coastal subsistence. J. Archaeol. Sci. 15:395-401.

Pauly, D. 1995. Anecdotes and the shifting baselines syndrome of fisheries. Trends Ecol. Evol. 10:430.

Pauly, D., V. Christensen, J. Dalsgaard, R. Froese, and F. Torres Jr. 1998. Fishing down marine food webs. Science (Washington, D.C.) 279:860-863.

Pinnegar, J. K., and G. H. Engelhard. 2008. The 'shifting baseline' phenomenon: A global perspective. Rev. Fish Biol. Fish. 18:1-16.

Pletka, S. M. 2001. The economics of Island Chumash fishing practices. Pages 221-244 in J. Arnold, ed. The origins of a Pacific Coast chiefdom: The Chumash of the Channel Islands. University of Utah Press, Salt Lake City.

Reitz, E. J. 2004. "Fishing down the food web": A case study from St. Augustine, Florida, USA. Am. Antiq. 69:63-83.

Rick, T. C. 2007. The archaeology and historical ecology of Late Holocene San Miguel Island. Cotsen Institute of Archaeology, University of California, Los Angeles.

Rick, T. C., and J. M. Erlandson, eds. 2008. Human impacts on ancient marine ecosystems: A global perspective. University of California Press, Berkeley.

Rick, T. C., J. M. Erlandson, T. J. Braje, J. A. Estes, M. H. Graham, and R. L. Vellanoweth. 2008a. Historical ecology and human impacts on coastal ecosystems of the Santa Barbara Channel region, California. Pages 77-102 in T. C. Rick and J. M. Erlandson, eds. Human impacts on ancient marine ecosystems: A global perspective. University of California Press, Berkeley.

Rick, T. C., J. M. Erlandson, and R. Vellanoweth. 2001. Paleocoastal marine fishing on the Pacific Coast of the Americas: Perspectives from Daisy Cave, California. Am. Antiq. 66:595-614.

Rick, T. C., J. M. Erlandson, R. L. Vellanoweth, and T. J. Braje. 2005. From Pleistocene mariners to complex hunter- 
gatherers: The archaeology of the California Channel Islands. J. World Prehist. 19:169-228.

Rick, T. C., J. M. Erlandson, R. L. Vellanoweth, T. J. Braje, P. W. Collins, D. A. Guthrie, and T. W. Stafford Jr. 2009. The origins and antiquity of the island fox (Urocyon littoralis): AMS ${ }^{14} \mathrm{C}$ dates from California's Channel Islands. Quat. Res. 71:93-98.

Rick, T. C., R. L. Vellanoweth, J. M. Erlandson, and D. J. Kennett. 2002. On the antiquity of the single-piece shell fishhook: AMS radiocarbon evidence from the southern California Coast. J. Archaeol. Sci. 29:933-942.

Rick, T. C., P. L. Walker, L. M. Willis, A. C. Noah, J. M. Erlandson, R. L. Vellanoweth, T. J. Braje, and D. J. Kennett. 2008b. Dogs, humans, and island ecosystems: The distribution, antiquity, and impacts of domestic dogs (Canis familiaris) on California's Channel Islands. Holocene 18 (7): 1077-1087.

Sandweiss, D. H., H. McInnis, R. L. Burger, A. Cano, B. Ojeda, R. Paredes, M. del Carmen Sandweiss, and M. Glascock. 1998. Quebrada Jaguay: Early South American maritime adaptation. Science (Washington, D.C.) 281:1830-1833.
Vellanoweth, R. L., T. C. Rick, and J. M. Erlandson. 2002. Middle and Late Holocene maritime adaptations on northeastern San Miguel Island, California. Pages 607-614 in D. R. Browne, K. L. Mitchell, and H. W. Chaney, eds. Proceedings of the 5th California Islands Symposium. Santa Barbara Museum of Natural History, Santa Barbara, California.

Vellanoweth, R. L., T. C. Rick, J. M. Erlandson, and G. Reynolds. 2006. A 6000-yearold red abalone midden from Otter Point, San Miguel Island, California. N. Am. Archaeol. 27 (1):69-90.

Walker, P. L., and M. J. DeNiro. 1986. Stable nitrogen and carbon ratios in bone collagen as indices of prehistoric dietary dependence on marine and terrestrial resources in southern California. Am. J. Phys. Anthropol. 71:51-61.

Walker, P. L., D. J. Kennett, T. Jones, and R. DeLong. 2002. Archaeological investigations of the Point Bennett pinniped rookery on San Miguel Island. Pages 628-632 in D. Browne, K. Mitchell, and H. Chaney, eds. Proceedings of the 5 th California Islands Symposium. Santa Barbara $\mathrm{Mu}-$ seum of Natural History, Santa Barbara, California. 